\title{
HISTORICAL AND MATERIAL APPROACH TO THE PAINTINGS AT THE PORTUGAL NATIONAL LIBRARY: CONTRIBUTIONS TO THE HISTORY OF CONSERVATION AND RESTORATION OF EASEL PAINTING IN THE $19^{\text {th }}$ CENTURY
}

\author{
C. M. Soares a, *, R. M. Rodrigues a, A. J. Cruz b, C. Rêgo b \\ a Institute of History of Art, Faculty of Humanities - University of Lisbon, Alameda da Universidade 1600-214 Lisboa, Portugal - \\ claramourasoares@fl.ul.pt \\ b Dept. of Conservation and Restoration, Polytechnic Institute of Tomar, Quinta do Contador - Estrada da Serra \\ 2300-313Tomar, Portugal - ajcruz@ipt.pt
}

KEY WORDS: Paintings, Convents, Conservation, Restoration, Nineteen century

\begin{abstract}
:
There are in the National Library of Portugal (BNP) about fifty paintings from former convents, mainly portraits executed between the sixteenth and nineteenth centuries, which are hung in rooms and along corridors, far from the eyes of the public and simultaneously protected by recent conservation and restoration interventions. These paintings, of little artistic interest, are, however, individual cases for the study of conservation and restoration interventions made in the nineteenth century. The data obtained will contribute to the history of paintings restoration, in terms of its practical aspects (about materials and techniques used), that is still to be written in Portugal.

Our research, which began in January 2011 and is predicted to end in December 2013, has been oriented by three complementary lines of action, with an interdisciplinary methodological base: the exploitation of the BNP's precious and unpublished documental archive; the assessment to the conservation status of the paintings and identification of restoration works; and the material study of the works, from physical and chemical methods of examination and analysis, in order to deepen our technical knowledge about the restoration of easel painting in the nineteenth century.

Through historical documents we could identify periods of restoration, restorers and materials used. The observation of paintings allowed selecting a set of twenty-seven pieces that showed old restorations, made in the nineteenth or early twentieth century. In addition it's very important to use examination methods and laboratory analysis to characterise the restoration works and the materials used.
\end{abstract}

\section{INTRODUCTION}

With the suppression of religious orders in Portugal, in 1834, and the subsequent nationalization of its assets, the State became responsible for a significant number of works of art, particularly religious in nature. To assist the management of the collections, several deposits were created, each one with thousands of pieces. We are particularly interested in the Deposit of the Libraries of the Extinct Convents, established at St. Francisco Convent, in Lisbon, in which not only a large part of the monastic libraries was directed to, but also thousands of religious paintings. The paintings that came to the Deposit, in general, were later dispersed among numerous public buildings, churches and museums around the country.

We intend to study the action of heritage protection exercised by the Deposit. The surveying and systematic analysis of the wealth of unpublished documents, has allowed for a much greater overall understanding of how the safeguarding carried out since 1834 operated. At the same time, it has also revealed essential information concerning the conservation and restoration treatment some works underwent, showing the materials and techniques used, and by which artists.

In addition, a material study of the National Library's paintings will be undertaken, particularly those that appear to have been little intervention during the 20th century, with a view to understand the restoration works carried out in the 19th century and to determinate the consequences of the process that began with the entrance of the paintings into the Deposit. This material study will be carried out by the laboratory study of the works.
It's essential to confront and complement the results coming from physical and chemical methods of examination and analysis with the information obtained through documental research, in order to compare theory with practice.

This study, based on both analytical and documental components, raises relevance that goes beyond the works of the Portuguese National Library. The documentation, which is exceptionally rich in information on the issues of protection and wealth management, contribute to the knowledge of the history of painting restoration in Portugal over a period about which very little is known. At the same time, it contributes to the same theme in terms of European knowledge.

\section{THE SET OF PAINTINGS}

The set consists mostly of portraits of religious figures or figures of the Portuguese court. There are also battle scenes and mythological representations alluding to Aeneas and the Trojan War.

Why are there religious paintings of the XVI-XIX centuries in a library built in the 1960's? This was a main issue and a focus point to develop this study.

Simultaneously, some of these old paintings seem to be relatively untouched by recent restoration works, which presents a rare opportunity to characterize the 19th and early 20th century restoration processes, often aggressive, that not only significantly changed the visible image of the work, as it had an impact on the degradation processes that occurred normally. 
A study of this nature is harder to do with works displayed in museums, subject to regular operations, maintenance and renovation that will erase the marks of earlier interventions. Thus, this study will contribute decisively to the knowledge of the history of conservation and restoration of paintings in Portugal during the 19th and early 20th century, by the articulation of the historic and documentary survey with the laboratory studies.

The paintings have had little interest among art historians due to its low artistic quality. However, provide a rare opportunity to study the criteria and materials used in old restoration works.

\section{THE KNOWLEDGE PROVIDED BY THE HISTORICAL ARCHIVES}

The archive documents and some testimonies published at the time are essential sources for correct historical research into the theory and techniques used in conservation and restoration works. These documents have provided new and important information to the understanding of the value of National Library's pictorial heritage in the nineteenth century, as well as the conservation problems that the paintings have or had.

\subsection{Convent of San Francisco: conditions of the space where the paintings were}

The choice of the convent of San Francisco as a deposit of the spoils of the religious houses was due to its central location and the strength of its construction, revealing, therefore, that this building seemed suitable for this purpose.

But the old Franciscan convent immediately showed that it was unsuitable for the intended new functions. The infiltration of rainwater appears to have been the biggest problem, presenting itself as a real risk to the collections deposited in the building.

The water and moisture, dust, moths and poor ventilation were the main problems of the building.

\subsection{Conservation state of the paintings}

The poor condition of the paintings seems to have been a reality. Several witnesses in the nineteenth century talk about it. Many paintings remained rolled, folded and stacked.

The weaknesses of the building and the bad storage conditions caused many paintings to be considered lost in 1844. Even in this state, José Feliciano de Castilho de Barreto e Noronha (1810-1879) considered that all works should be saved, but this was not the understanding of those who followed him in the direction of the National Library. Therefore, in 1853, a significant number of paintings were burned, since many were in ruins or consisted only of rags.

In the late 1890s, Gabriel Pereira, then director of the National Library, said that he had found the pictures, almost all poorly maintained.

Several actions were responsible for reducing drastically the number of paintings that were in the National Library. Currently, there are a little more than fifty paintings from the extinct convents.

\subsection{Restoration works carried out in the nineteenth century}

The history of conservation and restoration of painting is not done in Portugal. Internationally, studies are fragmentary and are directed mainly to the great masters.

In the paintings of the National Library of Portugal, through archival documentation, we were able to identify three moments in which the paintings of the deposit of San Francisco were intervened with.

We noted restoration works in 1835 , in 1864 and in 1888 . The first was made by the painter André Monteiro da Cruz (17701851), the second by João António Gomes and António da Costa e Oliveira and the third by the painter Luciano Martins Freire (1864-1934). If Luciano Freire is a well-known artist, this is not the case with others. Those are names that have been little studied in the field of painting as in the field of restoration. The documentation is not always rich, both for work performed and the materials used.

In 1835 , we know that the most treasurable works, made by the sixteenth-century Portuguese painter Grão Vasco, were "repaired"; the necessary stretchers for paintings on canvas were made; and some works were cleaned and "prepared".

We note a great concern with a few works, considered masterpieces. There isn't the same concern with all the works. Until this moment, based on the documentation, we knew little about materials and techniques used in the restoration for this phase.

In relation to the restoration of 1864 , we have information that about seventy portraits were restored (Figure 1). Its "cleanup and restoration" was made, and of their respective frames, and numerous materials in the old drugstore F.J.Carvalho (Lisbon) were acquired.

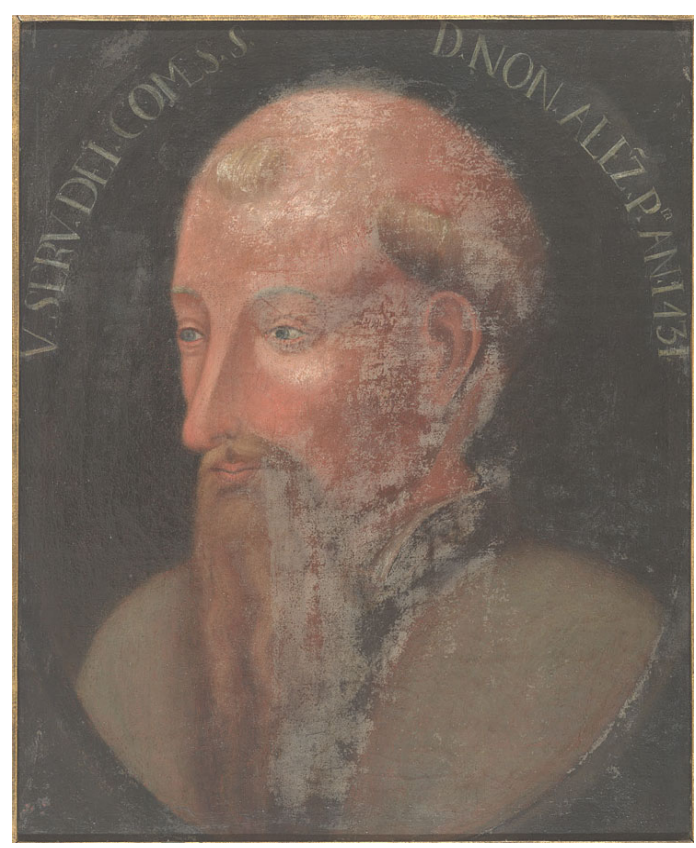

Figure 1: Unknown Author, Portrait of Frei Nuno de Santa Maria, seventeenth century (?), oil on canvas, $42.5 \times 35.5 \mathrm{~cm}$, National Library. Painting restored in 1864. 
The following materials were purchased, and among them various pigments:

\begin{tabular}{|l|l|}
\hline Dark green & English oil \\
\hline Dragon's blood & Turpentine \\
\hline English blue & $\begin{array}{l}\text { Ceruse in powder } \\
\text { form }\end{array}$ \\
\hline Shadow of Cologne & Alcohol $40^{\circ}$ \\
\hline Painter's gypsum & Shellac \\
\hline Black of Italy & Fine potash \\
\hline Ochre & Spirit varnish \\
\hline Anise flower & Chalk \\
\hline Reddle & Powdered faeces \\
\hline Ultramarine blue & $\begin{array}{l}\text { Black ("powder of } \\
\text { shoes") }\end{array}$ \\
\hline Peruvian green & Zumatic \\
\hline
\end{tabular}

Table 1. Materials for the restoration of 1864 .

This information, rarely provided by documentation, is extremely important for comparison with laboratory results, whose studies we expect to start next September. The data will help us to identify and characterize the old restoration works, and to date them. It's also essential to establish a relationship with the pigments used in Europe at the time, in order to retrieve more conclusions. The same applies to the restoration works of 1888. At that time, the famous painter-restorer Luciano Freire was commissioned to refresh and fix the inks that were used in many paintings of the National Library.

Luciano Freire did cleaning, retouching, varnishing and replacement of stretchers on a large number of works. Twentynine works restored by him were identified (Figures 2 and 3 ).

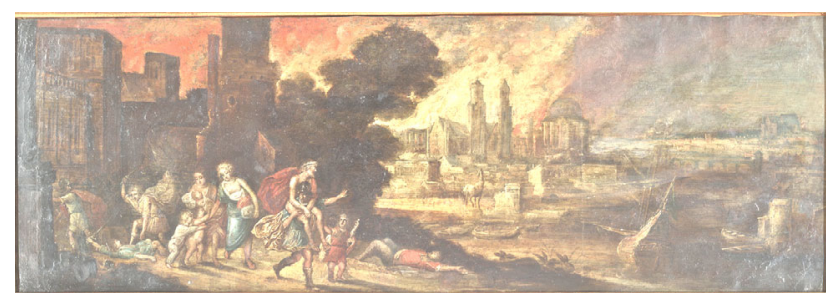

Figure 2: Diogo Pereira (attributed ), Fire of Troy, 1600-1650(?) oil on copper, $35,5 \times 86,5 \mathrm{~cm}$., National Library. Painting restored by Luciano Freire in 1888 .

We found also some lists of materials acquired for restoration. In these lists, which consist in receipts of purchases, we find:

\begin{tabular}{|l|l|}
\hline Milled ceruse & English green \\
\hline Turpentine & Imperial green \\
\hline Linseed oil & Reddle \\
\hline Chalk & $\begin{array}{l}\text { Black ("powder of } \\
\text { shoes") }\end{array}$ \\
\hline French secant & Ultramarine blue \\
\hline Powdered faeces & Peruvian green \\
\hline Bitumen & Light English green \\
\hline Glue from Oporto & Vermilion \\
\hline Zumatic & Dark green \\
\hline Sorrel salt & Painter's gypsum \\
\hline Plaster & Flatting varnish \\
\hline Alcohol $40^{\circ}$ & Crystal varnish \\
\hline
\end{tabular}

Table 2. Materials for the restoration of 1888 .

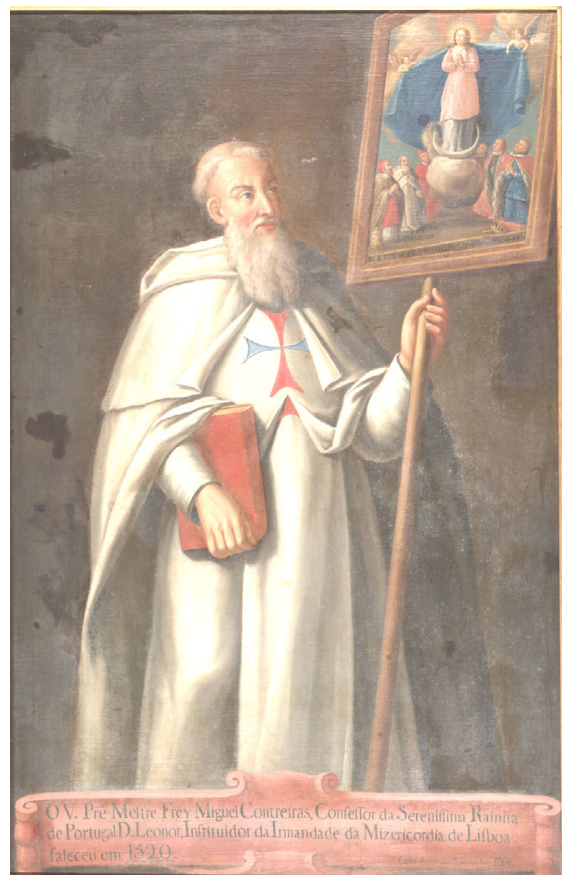

Figure 3: Carlos António Leoni, Portrait of Fray Miguel Contreiras, 1766 , oil on canvas, $187,5 \times 125 \mathrm{~cm}$, National

Library. Painting restored in 1864 and in 1888.

\section{EVALUATING THE CONSERVATION OF TWENTY- SEVEN PAINTINGS}

\subsection{Selection criteria}

After a careful observation of the set of monastic paintings, the conservator-restorer, who belongs to the research team, selected twenty-seven paintings. According to her, the others appear to have been restored more recently.

The observation was performed without optical observation equipment and without the execution of any method of examination and analysis. This is a pre-selection, which can be changed after use of laboratory resources.

\subsection{Assessment of the state of conservation of paintings}

The twenty-seven paintings observed received the following interventions:

\begin{tabular}{|l|c|}
\hline Interventions & Paintings \\
\hline Cleaning, varnishing and & 27 \\
touches & 11 \\
Occasional inpaintings & 21 \\
Fills surface & 3 \\
Inscriptions & 2 \\
Coloured masses & 3 \\
Patches & 2 or 24 \\
Linings & 2 \\
Cutting strips of canvas & 1 \\
Collage with synthetic & \\
adhesive & 2 or 20 \\
Stretchers & 1 \\
Application of tacks & \\
\hline
\end{tabular}

Table 3. Interventions identified in the 27 observed works. 
Cleaning, varnishing and touches are observed on all the selected paintings. This is visible by the absence of dirty aggregates, bright and thick varnish and by the colour change of retouching.

Occasionally, clearly visible in eleven works, the paintings show a different texture, a matte appearance and sometimes direct application on the support (without preparation). Filled surfaces are identifiable when compared to the original, mainly by the difference in texture.

There are three inscriptions in three paintings: a caption on the pictorial layer, another on a patch and a third on a paper glued on the stretcher.

In the reverse of two works, there was a thick layer of light brown paste on the support (which is not yet determined if it is original or not) and another thin and dark brown layer.

Cut strips of canvas are visible on two paintings, which don't have the surface layers of paint and textile backing in the peripheral areas.

Three paintings presented patches of different types (coarse cloth, cardboard, tape).

It is safe to say that the lining was done in two of the paintings. Although the observation at the back of the paintings have been difficult and limited, the appearance of the surface and the stiffness of the backing, leads us to suppose that there's more linings in 22 paintings, many of them executed with industrial textiles and wax-resin.

There is too a collage with synthetic adhesive, just in one painting on board.

For the same limitation that was indicated above, for now it is only possible to ensure that two stretchers are not original, because they don't have the corresponding dimensions of the paintings, but it seems that other 18 also result from restoration, by its appearance and by visible marks on the surface.

Many of the twenty-seven observed works have similar interventions, both from a technical standpoint, and in terms of materials used.

After analyzing the first data collected in the twenty-seven paintings, we considered that a further study in three works should be done: portraits of D. Afonso Henriques, of Friar John of Our Lady and Gentleman in the red hat (Figures 4, 5 and 6).

This selection focused in these works because they present multiple and distinct old restorations, from different dates. However, most of the data needs to be confirmed by examinations methods and laboratory analysis.

\subsection{Intervention criteria followed}

The conservation criteria was fully established over recent decades, involving respect for the works of art and the selection and justification of the procedures adopted in terms of materials and techniques, and implying as little invasive action as possible, were essentially non-existent before the 2 nd half of the 19th century (Cruz, 2007). Up until then, restoration work had involved general repainting, frequent stylistic and iconographic modifications, treatments using procedures and materials that were often kept as guarded secrets out of jealousy, but there are some references in a number of technical or, in particular, encyclopaedic works which confirmed that these were extremely aggressive. On one hand, the cleaning of easel paintings consisted in using brushes and sponges; and, on the other, it could employ the use of bleach, turpentine, whitewash or hot water, among other substances (Rodrigues, 2007; Serrão, 2006). It is possible that the procedures and materials used were similar to those in other countries.

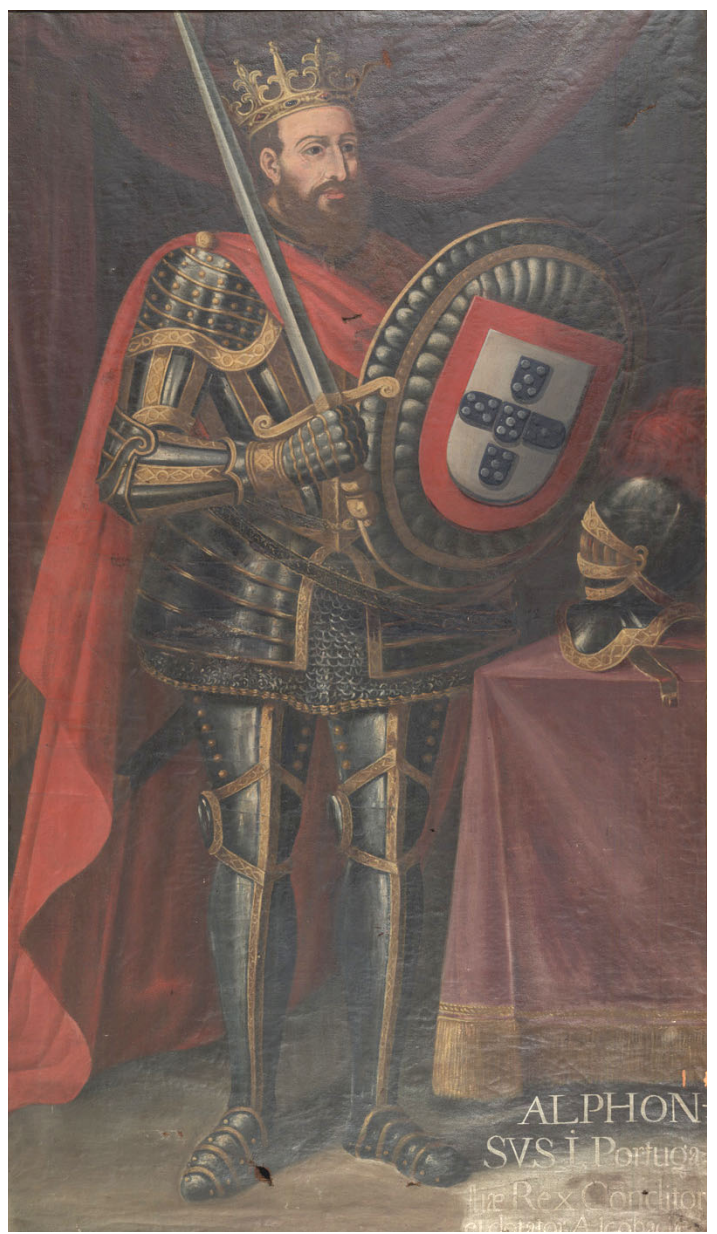

Figure 4: Unknown Author, Portrait of D. Afonso Henriques, the first king of Portugal, seventeenth century (?),oil on canvas, $224 \times 133 \mathrm{~cm}$., National Library.

Regarding the paintings from the National Library, we demonstrated that many restorations were usually identified as intending the "aesthetic" effect only. We find in all of them pictorial surface cleaning, varnishing, retouching and inpaintings.

About inpaintings (occasional or generalized), there are often differences in the same work. Sometimes the application of colour is made directly on the support, sometimes on a preparation, exceeding the limits of the lacunae in an invasive approach. This attitude gives us the indication that these interventions were not implemented with the principle of the maximum respect for the original work.

In most inpaintings, it is clear that a colour selection criteria was followed, although today the colour has changed. Therefore, it is unclear if the colour changed due to the natural aging process or due to poor technical mastery by the restorer. 
Overall, the intervention criteria followed does not correspond to the present criteria, especially the respect for original materials and the use of reversible and compatible materials that do not affect the original work.

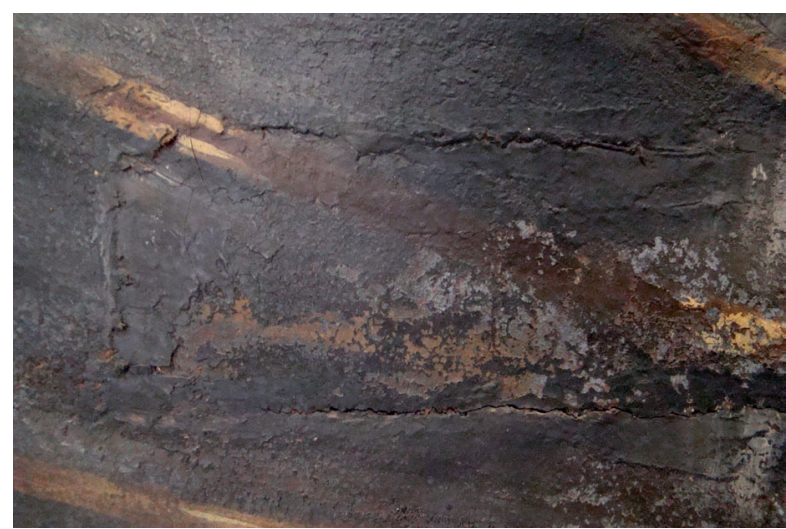

Figure 5: Portrait of D. Afonso Henriques. Detail of repaints on armor.

Thus, most of the work performed (varnishing, repainting, linings), exceeded what was necessary for the conservation of the paintings, moving away from what we understand today as minimal intervention.

Also, there is not an absolute respect for the original work, or the care to differentiate the techniques and materials used in the restoration work. Thus, most touches are performed with oil ink, mimicking the original lost areas. They are also sometimes large, concealed parts of the original surface.

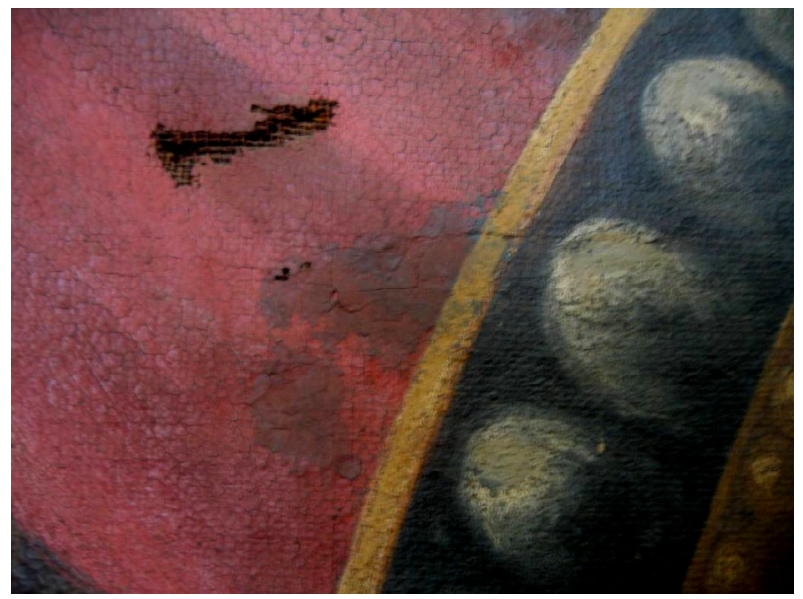

Figure 6: Portrait of D. Afonso Henriques. Detail of touches in the shield.

It is not possible to determine exactly the materials used in restorations at this point. However, it's clear that some materials, such as those used in the inpaintings and the adhesives of the linings are not reversible, because, according to what it is possible to observe, the first case ink oil was used, and in the second wax-resin.

As from the late 18th century, concerns about restoration work began to be voiced (Pietro Edwards, in Italy; the National Gallery, in England) (Bomford \& Leonard, 2004; Conti, 2002; Macarrón Miguel, 1997; Ruiz-Mateus, 1994), but such worries seem to have had little impact on restoration in Portugal, at least until the late 19th century (Cruz, 2007). In this period, some of the most illustrious Portuguese restorers, such as Manuel Macedo and, later, Luciano Freire, established some limits and criteria for restoration works, with the former writing, in 1885 , that "there are cases in which restoration damages" (Cruz, 2007).

\section{LABORATORY SUPPORT}

The material study, which is the third and final phase of the project and that will begin, as we said, in next September, will be carried out by a laboratory study of the works. Instead of the usual material characterization of the original paintings, as usual, this laboratory work on some of the paintings will consist of the detailed reconstitution of the restoration work carried: reconstructing the procedures followed, the materials used and the underlying restoration principles.

It will be essential to confront and complement the results coming from physical and chemical methods of examination and analysis with the information obtained through documental research.

Therefore, the aim is to study the restoration of the selected paintings with a view to answering questions such as the following:

- What kind of restoration work was carried out?

- How was it carried out?

- What was the scale of the restoration work?

- How were restoration materials used in relation to original materials?

-What materials were used in the restoration work?

- To what extent can the original materials be recognized?

- From the material point of view, was the restoration work justified in terms of how it was carried out?

- How did the restoration materials develop?

- What consequences could the restoration works have had as regards the conservation of the works?

- To what extent has the restoration work affected the current image?

To answer all these questions we shall mainly use examination methods and laboratory analysis to characterize the restoration work and the materials used. Laboratory studies of paintings usually focus as much as possible on the original materials of the paintings and not as significantly in the conservation and restoration work. Here, however, the examinations and analysis will focus principally on the restored areas.

Radiographs and technical photographs are a major part of this process. By its special nature, they can only be done with the support of the technicians of the photographic and radiographic laboratories at Polytechnic Institute of Tomar.

Therefore, it will be possible to characterize and understand the effects of this restoration work in detail, mainly in terms of image. Although our results will be based on a specific group of works, the information pertains to the material history of most paintings, which is usually difficult to obtain, but will hopefully be of general use.

We will then move on to identifying the materials used in the former restoration work through chemical analysis. Pigments, loads and binders will be determined. Whenever possible, noninvasive methods will be used, such as the spectrometry of $\mathrm{x}$ ray fluorescence for pigment identification, at the BNP itself. 
However, due to the limitations of these methods, we will need to use samples taken from the paintings. When relevant, similar analysis will be done on the original material. The materials identified in the restored areas will be compared to the archive documentation and the technical literature of the era. Due to its importance for our study, we hope to be able to present some results of laboratory experiments at the Congress poster presentation.

Assessing the works' state of conservation will enable us to learn about the problems displayed, the risk of loss as well as leading to proposals to ensure the safeguarding presented by the BNP paintings.

\section{FINAL REMARKS}

The great importance and originality of this project, with its interdisciplinary methodological base, stems from two decisive factors: the existence of innumerable unpublished historical documents; and the rare opportunity to study old restorations, since the most recent restorations tend to "erase" the previous ones.

The data obtained is important in the history of art, and might be crucial for the conservation and restoration. The materials used above may influence the choice of products to be used in future restoration interventions, particularly in respect of consolidates or solvents used in cleaning (Cruz, 2000).

With the data obtained, we will contribute to the knowledge of the history of conservation and restoration of paintings in the nineteenth century, both in Portugal and in Europe.

Bearing in mind that bringing such studies to the attention of various sectors of the public is increasingly a guarantee of heritage sustainability, in parallel with academic studies aimed at a more specialized group, the challenge is to find other forms of spreading this new information, which will create greater interest and curiosity in a wider-ranging public, uniting enjoyment and knowledge. To this end, there are plans to create a dissemination program based on modern technology (Internet page and electronic voice and image kiosk), in order to deliver this information to an audience as wide as possible.

\section{REFERENCES}

Bomford, D. (et al.), 2004. Issues in the Conservation of Paintings, Los Angeles, The Getty Consevation Institute.

Conti, A., 2002. Storia del restauro e della Conservazione delle Opere d'Arte, Milano, Electa.

Cruz, A. J., 2007. Em busca da imagem original: Luciano Freire e a teoria e a prática do restauro de pintura em Portugal cerca de 1900. In: Conservar Património, 5, pp. 67-83.

Cruz, A., J., 2000. A matéria de que é feita a cor. Os pigmentos utilizados em pintura e a sua identificação e caracterização. 1.os Encontros de Conservação e Restauro - Tecnologias, Instituto Politécnico de Tomar.

http://5cidade.files.wordpress.com/2008/04/a-materia-de-que-efeita-a-cor.pdf (accessed 15 June 2012).

Macarrón Miguel, Ana Maria, 1997. Historia de la Conservación y la Restauración, Madrid, Editorial Tecnos, S.A.
Rodrigues, P. S., 2007. Da História da Conservação e do Restauro: Das Origens ao Portugal Oitocentista. In: 40 Anos do Instituto José de Figueiredo, Lisboa, Instituto Português de Conservação e Restauro, pp. 17-38.

Ruiz-Mateus, Maria, 1994. Conservadores y restauradores en la historia de la conservación y restauración de bienes culturales, Sevilla, Gráficas Olímpia.

Serrão, V., 2006. «Renovar», «repintar», «retocar»: estratégias do pintor-restaurador em Portugal, do século XVI ao XIX. Razões ideológicas do iconoclasma destruidor e da iconofilia conservadora, ou o conceito de «restauro utilitarista» versus «restauro científico». In: Conservar Património, 3-4, pp. 53-71.

\section{ACKNOWLEDGEMENTS}

The authors wish to acknowledge to the Portugal National Library and to the Fundação para a Ciência e a Tecnologia (FCT) for their financial support through the Eneias Project The collection of painting at the Portugal National Library: from saving of convent artistic heritage during the Liberal Revolution to an integrated study of conservation and dissemination (PTDC/HIS-HEC/113226/2009). Co-ordinator: Clara Moura Soares, Institute of History of Art, Faculty of Humanities - University of Lisbon, Portugal. 